\title{
PREVENTIVE EFFECT OF D-GLUCARATE AGAINST RENAL DAMAGE INDUCED BY KANAMYCIN
}

\author{
Koji Furuno, Shuzo Matsubara, Kunio Ando and Shigeo Suzuki \\ Research Laboratories, Chugai Pharmaceutical Co., Ltd. \\ Toshima-ku, Tokyo, Japan \\ Kozo Hirata \\ Department of Urology, Faculty of Medicine, \\ Kyushu University, Fukuoka, Japan
}

(Received for publication June 15, 1976)

\begin{abstract}
Kanamycin-induced renal impairment in dehydrated rats was spared by the administration of sodium D-glucaro-1,4-lactone. In the plasma elimination and urinary excretion studies, D-glucarate-treated rats showed quick removal of the antibiotic from the body as compared with non-treated rats. Organ distribution study clearly demonstrated the potent nephrotoxicity of kanamycin and the reduction effect of D-glucarate against the nephrotoxicity. The drug level in the kidney in non-treated rats was more than two orders of magnitude higher than those in other organs such as the liver, lung and spleen, and remained high for 48 hours after antibiotic administration. In D-glucarate-treated rats the kidney content of the drug was diminished as compared with non-treated rats just after the antibiotic administration, followed by a gradual decline with time.
\end{abstract}

The aminoglycoside class of antibiotics is highly effective against a wide variety of bacterial infections. However, their usefulness in humans is strictly restricted by two serious side effects, nephrotoxicity and ototoxicity ${ }^{1 \sim 3)}$. Recently, we have shown that dehydrated rats regularly developed acute renal failure following aminoglycoside injection but were spared by D-glucarates treatment ${ }^{4)}$. The protective effect was prevalent among hexauronic and hexaaldonic acids, although to a lesser degree, but not to a hexaaldose, sugar alcohols, substances in the TCA cycle and other acidic compounds. We report here the effect of sodium D-glucaro-1,4-lactone on distribution and excretion of kanamycin in dehydrated rats.

\section{Materials and Methods}

Renal failure was produced in dehydrated rats which are much more susceptible to aminoglycoside nephrotoxicity than normal rats. Male Wistar-Imamichi rats weighing $200 \sim 300 \mathrm{~g}$ were maintained without water for 48 hours. The dehydrated rats were administered intraperitoneally with saline or $400 \mathrm{mg} / \mathrm{kg}$ of D-glucaro-1,4-lactone 5 minutes before antibiotic injection. Kanamycin sulfate dissolved in physiological saline solution was then injected intramuscularly in a dose volume of $0.5 \mathrm{ml}$ per animal. After antibiotic injection the rats were placed in individual metabolic cages with free access to water. Rats were employed three animals per group. Concentration of blood urea nitrogen (BUN) was measured by a Unigraph (Warner-Chilcott) and urinary occult blood by Labstix (Ames Division). Antibiotics levels were determined by disc method with Bacillus subtilis ATCC-6633 as the test organism.

\section{Results and Discussion}

The protective effect of D-glucarate on antibiotics-induced renal impairment was represented in Fig. 1. Following injection of kanamycin, dehydrated rats revealed an obstruction of urine output 
straight away and occult blood in the urine for 24 hours, accompanied by elevation of BUN from 3 to 24 hours at which time the highest value was found. Administration of D-glucarate in dehydrated rats led to a slight symptom of renal dysfunction. Dehydrated rats began urination a few hours after being given sufficient water and excrete large volumes of urine for 24 hours. Therefore, D-glucarate had no diuretic effect.

The pattern of plasma elimination and urinary excretion of kanamycin after administration in dehydrated rats were illustrated in Fig. 2. In D-glucarate-treated rats, the antibiotic was eliminated quickly from the blood and most of the drug was excreted during the first 3 hours after injection. In contrast, non-treated rats showed slow disappearance of the drug from the blood in accordance with delayed finish of drug urinary excretion. When kanamycin was administered in normal rats, it was eliminated from the blood with a biological half life of 0.63 hours and was completely excreted into the urine in a few hours. Accordingly, previous data seem to indicate that D-glucarate-treated rats normally removed the antibiotics from the body, and that excretion of the drug is impaired in nontreated rats probably because of renal insufficiency. In support of this view, it was observed that dehydrated rats receiving saline rapidly cleared kanamycin with the same plasma half life ( 0.59 hours) as those receiving D-glucarate when the administration dose of antibiotics was decreased to 50 $\mathrm{mg} / \mathrm{kg}$ at which only slight renal dysfunction was detected (Table 2).

Table 1 shows that renal failure was induced by the enhancement of antibiotic accumulation into the kidney tissue. The concentration of kanamycin in the kidney was over two orders of

Fig. 1. Preventive effect of D-glucarate against kanamycin-induced renal damage in dehydrated rats.

Dehydrated rats receiving saline ( or $400 \mathrm{mg} / \mathrm{kg}$ of sodium D-glucaro-1,4-lactone $(\mathrm{O})$ were injected with kanamycin-sulfate in doses of $300 \mathrm{mg}$ as the base $/ \mathrm{kg}, 5$ minutes later.

Three animals were employed at defined time for each group.

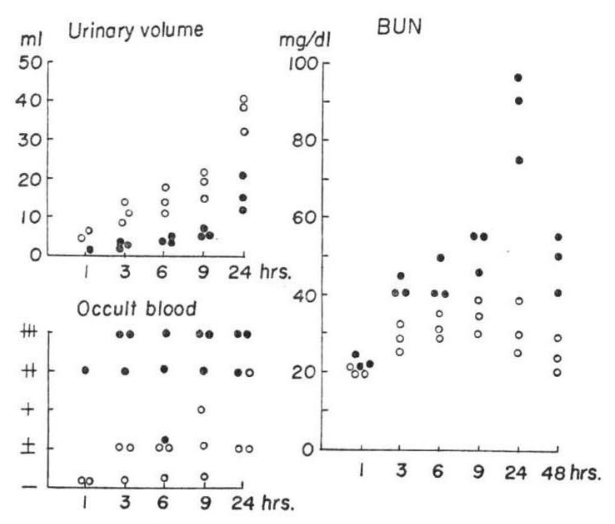

Fig. 2. Plasma levels and urinary excretion of kanamycin in dehydrated rats.

Values are means for three heads of animals which were the same ones as in Fig. 1.
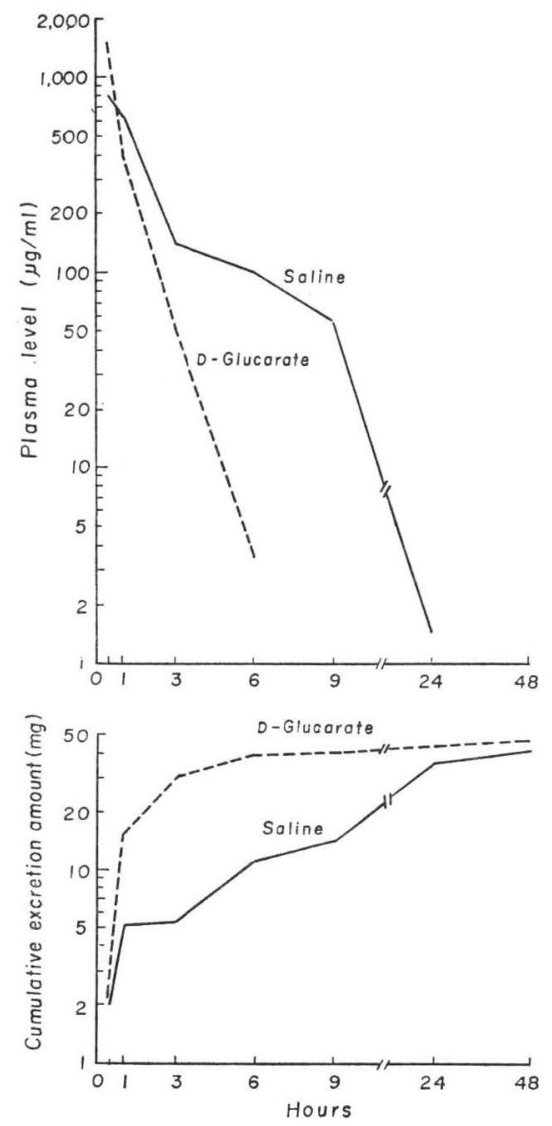
Table 1. Levels of kanamycin in various organs after an intramuscular dose of $300 \mathrm{mg} / \mathrm{kg}$ of $\mathrm{kanamycin}$

\begin{tabular}{|c|c|c|c|c|c|c|c|c|}
\hline \multirow{2}{*}{ Organ } & \multirow{2}{*}{ Drug** } & \multicolumn{7}{|c|}{ Time after injection (hours) } \\
\hline & & $1 / 2$ & 1 & 3 & 6 & 9 & 24 & 48 \\
\hline Kidney & $\begin{array}{l}\text { Saline } \\
\text { D-Glucarate }\end{array}$ & $\begin{array}{l}2730 \pm 400 * \\
1900 \pm 277\end{array}$ & $\begin{array}{l}2880 \pm 1100 \\
1150 \pm 187\end{array}$ & $\begin{array}{r}1330 \pm 230 \\
850 \pm 178\end{array}$ & $\begin{array}{r}1780 \pm 94 \\
680 \pm 47\end{array}$ & $\begin{array}{r}1520 \pm 455 \\
560 \pm 164\end{array}$ & $\begin{array}{c}1750 \pm 575 \\
450 \pm 47\end{array}$ & $\begin{array}{c}1550 \pm 250 \\
330 \pm 64\end{array}$ \\
\hline Lung & $\begin{array}{l}\text { Saline } \\
\text { D-Glucarate }\end{array}$ & $\begin{array}{l}56.3 \pm 13.8 \\
48.3 \pm 5.0\end{array}$ & $\begin{array}{l}42.0 \pm 1.4 \\
24.7 \pm 7.5\end{array}$ & $\begin{array}{l}7.8 \pm 4.4 \\
2.8 \pm 0.8\end{array}$ & $\begin{array}{l}7.8 \pm 3.0 \\
0.9 \pm 0.1\end{array}$ & $\begin{array}{r}4.0 \pm 2.5 \\
\text { 二*** }\end{array}$ & $1.2 \pm 0.4$ & $1.5 \pm 0.5$ \\
\hline Liver & $\begin{array}{l}\text { Saline } \\
\text { D-Glucarate }\end{array}$ & $\begin{array}{l}14.5 \pm 2.0 \\
20.5 \pm 2.3\end{array}$ & $\begin{array}{l}9.2 \pm 3.3 \\
7.5 \pm 1.1\end{array}$ & $\begin{array}{l}8.4 \pm 2.0 \\
3.0 \pm 0.8\end{array}$ & $5.0 \pm 2.7$ & $4.1 \pm 2.1$ & $\begin{array}{c}3.8 \pm 2.2 \\
-\end{array}$ & $\begin{array}{c}3.3 \pm 0.8 \\
-\end{array}$ \\
\hline Spleen & $\begin{array}{l}\text { Saline } \\
\text { D-Glucarate }\end{array}$ & $\begin{array}{l}20.0 \pm 1.4 \\
18.3 \pm 1.7\end{array}$ & $\begin{array}{l}9.2 \pm 1.0 \\
8.0 \pm 1.1\end{array}$ & $\begin{array}{l}4.9 \pm 2.2 \\
2.2 \pm 0.6\end{array}$ & $\begin{array}{l}5.0 \pm 0.7 \\
1.7 \pm 0.3\end{array}$ & $\begin{array}{l}4.0 \pm 1.9 \\
1.8 \pm 0.2\end{array}$ & $\begin{array}{l}3.5 \pm 1.6 \\
1.4 \pm 0.2\end{array}$ & $\begin{array}{l}3.0 \pm 1.2 \\
0.8 \pm 0.1\end{array}$ \\
\hline
\end{tabular}

*: $\quad \mu \mathrm{g} / \mathrm{g}$ wet weight, mean \pm S.D. of three heads of rats which are the same ones in Fig. 1.

**: Saline or D-glucarate $(400 \mathrm{mg} / \mathrm{kg})$ was given intraperitoneally at 5 minutes before injection of kanamycin-sulfate.

***: Less than $0.05 \mu \mathrm{g} / \mathrm{g}$ by agar-disc diffusion method with Bacillus subtilis ATCC-6633.

magnitude higher than that in other organs such as the liver, lung and spleen. The greatest amount of drug in the kidney content corresponded to about $8 \%$ of dose administered. The kidney in non-treated rats gave different pattern of time course for drug level from that in D-glucaratetreated rats. The drug level in the kidney in nontreated rats decreased half as much $1 \sim 3$ hours after antibiotic injection but thereafter remained high for 48 hours, whereas that in D-glucaratetreated rats was on the decrease with time. Furthermore, apparently greater kidney drug level than that in D-glucarate-treated rats was observed in non-treated rats at 0.5 hour (the earliest time) after antibiotic injection. Reduction of kanamycin distribution in the kidney by D-glucarate was obtained even in the case of a chemotherapeutic administration dose at which identical plasma level of the drug was found both with dehydrated rats receiving either saline or $\mathrm{D}$-glucarate (Table 2). It is suggested from these results that the antibiotic was taken up by the kidney cells, and which D-glucarate directly suppressed.

Administration of D-glucarate in dehydrated rats also resulted in the decrease of drug levels in other organs. It was observed that the drug levels in these organs paralleled those in the kidney with both rats groups. The drug levels in those organs for non-treated rats were not apparently higher than those for D-glucarate-treated rats at the earliest time after antibiotic injection at which a similar drug level was found with both rats groups, and gave the progressive decrease in time. It is likely that the drug content in these organs was governed by the drug level in the plasma, and that D-glucarate did not directly suppress the drug distribution in those organs. Lower drug level in these organs than in the plasma and similar drug level among them also support this view.

Clearance studies suggest that aminoglycoside antibiotics are excreted primarily as a function of the glomerular filtration rate. ${ }^{5)}$ According to morphologic study by HiRATA et al. ${ }^{\text {) }}$, aminoglycoside- 
induced renal failure in dehydrated rats is responsible for necrosis of the epithelial cells of proximal convoluted tubules. It seems that $\mathrm{D}$-glucarate exerts their preventive effect by suppressing the reabsorption of antibiotic into the cells of renal tubules.

\section{References}

1) Farrington, R. F.; H. Hull-Smith, P. A. Bunn \& W. McDermott: Streptomycin toxicity. J. Amer. Med. Ass. 134: 679 688, 1947

2) UedA, Y.: Renal damage. Kekkaku (Japan) 39: 346 348, 1964

3) FineGold, S. M.: Toxicity of kanamycin in adults. Ann. N. Y. Acad. Sci. 132: 942 956, 1966

4) Furuno, K.; K. Ando, S. Suzuki \& K. Hirata: Effect of D-glucarates on basic antibiotic-induced renal damage in rats. J. Antibiotics 29: 187 194, 1976

5) Tisch, D. E.; J. B. Huftalen \& H. L. Dickison: Pharmacological studies with kanamycin. Ann. N. Y. Acad. Sci. 76: 44 65, 1958

6) Hirata, K.; T. Ueda, K. Morita, H. Hirata, C. Takamatsu, K. Goto, H. Hirata, R. Aramaki, M. KAI \& T. IsHIKAwA: Studies on pathogenesis of acute renal failure after administration of antibiotics with plasma expander. Jap. J. Nephrol. 15: 371 391, 1973 